\title{
Studying the behavior of geopolymer concretes under repeated loadings
}

\author{
Osamah M. G. Al-Kerttani ${ }^{*}$ id and Ammar Mutar
}

\author{
*Correspondence: osama_moh75@ \\ yahoo.com; osama.mohammed@ \\ uomustansiriyah.edu.iq \\ Civil Engineering Department, \\ College of Engineering, \\ Mustansiriyah University, Baghdad, \\ Iraq
}

\begin{abstract}
This article investigates utilization of polypropylene microfibers as reinforcement in geopolymer concrete to enhance the ductility characteristics since the geopolymer concrete is considered a brittle material. The polypropylene microfibers were added to geopolymer concrete at the fiber volume content of $0.5 \%, 1.0 \%$, and $1.5 \%$. In this article, a slump test and compressive strength were tested for geopolymer concretes to measure the effect of polypropylene microfibers on geopolymer concretes. Also, static flexural strength and dynamic loading were applied to find out the attitude of polypropylene fiber-reinforced geopolymer concrete and to measure both the deflection and number of load cycles until failure. While comparing the results with reference geopolymer concrete, all samples were tested at 28 days and, finally, a statistical test was carried out. The results concluded that the use of polypropylene microfibers improves the compressive strength and enhances the properties of polypropylene fiber-reinforced geopolymer concretes, increases the loading for the appearance of the first crack, and decreases the deflection of polypropylene fiberreinforced geopolymer concretes compared with reference geopolymer concrete.
\end{abstract}

Keywords: Deflection, First crack, Flexural strength, Geopolymer, Polypropylene fiber

\section{Introduction}

Sustainable growth in construction includes the following: using innovative materials and reusing waste and nonconventional materials to preserve raw materials and discover alternate methods for environmental preservation [1].

Geopolymers are minerals, usually ceramic, materials that form long-range, covalently bonded, non-crystalline (amorphous) networks. The characteristics and use of geopolymers are being surveyed in many industrial and scientific specifications such as geology, colloid chemistry, modern inorganic chemistry, mineralogy, and physical chemistry and in other applications of engineering procedures techniques. The field of geopolymers is a division of polymer science, technology, and chemistry that sort as a part of the basic rules of materials science [2].

Kim et al. [3] showed that geopolymers can be divided into two basic groups: pure mineral geopolymers and organic ones, which contain geopolymers, artificial analogs of naturally occurring macromolecules.

(c) The Author(s) 2021 Open Access This article is licensed under a Creative Commons Attribution 4.0 International License, which permits use, sharing, adaptation, distribution and reproduction in any medium or format, as long as you give appropriate credit to the original author(s) and the source, provide a link to the Creative Commons licence, and indicate if changes were made. The images or other third party material in this article are included in the article's Creative Commons licence, unless indicated otherwise in a credit line to the material. If material is not included in the article's Creative Commons licence and your intended use is not permitted by statutory regulation or exceeds the permitted use, you will need to obtain permission directly from the copyright holder. To view a copy of this licence, visit http://creativecommons.org/licenses/by/4.0/. The Creative Commons Public Domain Dedication waiver (http://creativecommons.org/publicdomain/zero/1.0/) applies to the data made available in this article, unless otherwise stated in a credit line to the data. 
Normal concrete which was manufactured by Portland cement can be replaced by geopolymer concrete (GPC) since it is an environmentally friendly component and unparalleled sustainable to substitute [4]. A lot of materials can be used to make geopolymer, such as alumina-silicate materials (source fly ash (FA) and slag which are by-product materials also and geological materials origin such as metakaolin (MK) [5] considered as source materials. The productions of these pozzolanic materials produces less $\mathrm{CO}_{2}$ and energy compared with the manufacture of Portland cement.

So, for preserving the environment to make it free from pollution and sustainability of raw materials, making of concrete using geopolymers as the binder has drawn the attention of many researchers [6]. The combination of sodium hydroxide $(\mathrm{NaOH})$ and sodium silicate $\left(\mathrm{Na}_{2} \mathrm{SiO}_{3}\right)$ is the major alkaline solution used in geopolymerization [7-10].

The combination of fiber with the brittle matrix is an effective method to enhance flexural strength and toughening mechanisms since it eliminates the crack development under various loading and environmental effects such as shrinkage [11, 12].

In contrast to most ceramics, a large domain of fibers, consisting of organics, can be utilized as reinforcement in the geopolymer due to the temperature of the geopolymers being close to ambient temperature [13]. Polypropylene (PP) was first utilized as reinforcement for concretes, to enhance their flexural strength. Thus, tests were also made to utilize it to reinforce composites based on geopolymers. So, PP fibers were a major of the first fibers which were added to geopolymers $[12,14,15]$. Therefore, Zhang et al. found that the early flexural strength of the composite which contain $0.75 \%$ polypropylene fiber (PPF) was improved about two times after 1 and 3 days [16].

Zhu et al. [17] wrote an article with the utilization of fly ash-based geopolymers with $1.5 \%$ PPF by volume (length of $30 \mathrm{~mm}$ and $1 \mathrm{~mm}$ in diameter). The specimens were subjected to a high temperature $85^{\circ} \mathrm{C}$ for $10 \mathrm{~h}$. The results showed that there was an improvement in mechanical properties. The compressive strength of the PPF composites was $91.7 \mathrm{MPa}$ compared with $70 \mathrm{MPa}$ for the matrix, while the results clarified the flexural strength were respectively 8.4 MPa for the composite and 7.1 MPa for the matrix material. Meanwhile, Zhu et al. tested the tensile strength, and there was an enhancement from 3.1 MPa for the matrix material to 6.4 MPa for the composite with PPF.

This kind of composite can be used as fireproof barriers in buildings since it has an excellent immovability against cracking at higher temperatures $[8,18]$. Also, isolation and lightweight construction materials could be used this type of material [18].

Wang et al. [18] have investigated foamed geopolymers reinforced by PPF with fly ash. Fibers were with a diameter of $0.017 \mathrm{~mm}$ and length between 3 and $19 \mathrm{~mm}$, and the volume of fibers added was $0.5 \%, 1.0 \%, 1.5 \%$, and $2.0 \%$. The superior indications were done for $0.5 \%$ PPF. The increment in compressive strength of fiber-reinforced composites with $3,6,9,12$, and $19 \mathrm{~mm}$ lengths compared to reference mixes was $57 \%$, $46 \%, 57 \%, 71 \%$, and $6 \%$ respectively.

Pham et al. [19] reached better results for mechanical properties when tested two lengths of PPF with $50 \mu \mathrm{m}$ in diameter and lengths of 10 and $15 \mathrm{~mm}$. PPF was added in amount of $0.5,1.0$, and $1.5 \%$ by volume to geopolymer matrix based on fly ash. The 
values showed enhancement in compressive strengths in addition to flexural strengths for both PPF lengths. The best values were reached for shorter PPF of $10 \mathrm{~mm}$ lengths. The compressive strength of $0.5 \% \mathrm{PPF}$ was $43.3 \mathrm{MPa}$ compared with $32.0 \mathrm{MPa}$ for normal matrix, while the flexural strength had $8.0 \mathrm{MPa}$ with a $1.5 \%$ PPF compared to 5.9 MPa for conventional concrete.

Behforouz et al. [20] tested geopolymers based on metakaolin with aggregates were reinforced by PPF of diameter $20 \mu \mathrm{m}$ and length $6 \mathrm{~mm}$. The PPF were put in the mix at $0.3,0.5$, and $1.0 \%$ by mass. The values did not show a difference in compressive strength; the strength of the reference specimen was $52.6 \mathrm{MPa}$ compared to $53.1 \mathrm{MPa}$ with 1\% PPF. On the other hand, the flexural strength increases from $3.6 \mathrm{MPa}$ for control mixes to $3.8,4.2$, and $4.9 \mathrm{MPa}$ when $0.3 \%, 0.5 \%$, and $1.0 \% \mathrm{PPF}$ were added; same results were made by Yuan et al. [21].

Because of thermal insulation and lightweight of PPF, it is considered as most commonly used between different kinds of fibers [22-24] and also due to the advantages of PPF such as resistance to high temperature which reached $900^{\circ} \mathrm{C}$ and high resistance to aggressiveness of environment [25].

\section{Methods}

\section{Research motivation}

There are a lot of articles published dealing with geopolymer concretes characteristics such as mechanical properties and applications of this new type of concretes. Thus, the goal of this study is to find out the dynamic properties of PPFGPC under repeated loading and the deflection of PPFGPC when subjected to static and repeated loading when reinforced with $0.5,1.0$, and $1.5 \%$ by volume in addition to reference mix. For this, four mixes were mixed to test the slump flow in the fresh state of PPFGPCs, and then 12 cubes of $10 \times 10 \times 10 \mathrm{~cm}$ and 18 slabs with $40 \times 40 \times 5 \mathrm{~cm}$ were cast and classified into two groups, the first group which includes 0.0 and $0.5 \%$. PPF investigated the ability of slabs to withstand the repeated loading until failure and the deflection during this recycling loading. In the second group, which consists of 0.0, 0.5, 1.0, and $1.5 \%$ PPF, the deflection during flexural strength until failure was tested and the load of the first cracks in both groups was observed. After that, the statistical test was carried out according to the ANOVA test.

\section{Materials}

In this work, the source of materials used was metakaolin MK which is conformed to ASTM C 618 [26]. The chemical composition and physical properties of MK are shown in Table 1. In this work, the alkaline solution used was $\mathrm{NaOH}$ and $\mathrm{Na}_{2} \mathrm{SiO}_{3}$ liquids. The mass ratio of $\mathrm{NaOH}$ to $\mathrm{Na}_{2} \mathrm{SiO}_{3}$ solution used was 0.4 is used. The lucidity of $\mathrm{NaOH}$ which is available in the state of pellet is $99 \%$; the solution consisting of $\mathrm{NaOH}$ and water gave a concentration of $14 \mathrm{M}$.

The fine aggregate used is Al-Ekhadir natural sand which, passing from the sieve $1.18 \mathrm{~mm}$, has a specific gravity of 2.6 and a broken natural coarse aggregate with 10 $\mathrm{mm}$ maximum size with a specific gravity of 2.7. Also, the superplasticizer (SP) type F in accordance to ASTM C494-19 [27] was used to reach the required workability. The 
Table 1 Chemical analysis and physical properties of metakaolin

\begin{tabular}{ll}
\hline Oxides & Content\% \\
\hline $\mathrm{SiO}_{2}$ & 54.2 \\
$\mathrm{Al}_{2} \mathrm{O}_{3}$ & 39.00 \\
$\mathrm{Fe}_{2} \mathrm{O}_{3}$ & 0.92 \\
$\mathrm{CaO}$ & 1.37 \\
$\mathrm{MgO}$ & 0.15 \\
$\mathrm{SO}_{3}$ & 0.45 \\
$\mathrm{Na}_{2} \mathrm{O}$ & 0.22 \\
$\mathrm{~K}_{2} \mathrm{O}$ & 0.27 \\
$\mathrm{LOI}$ & 0.71 \\
$\mathrm{TiO}_{2}$ & 0.8 \\
Physical properties & \\
Physical form & \\
Color & Powder \\
Specific gravity & Off-white \\
Surface area, $\mathrm{m}^{2} / \mathrm{g}$ & 2.64 \\
\hline
\end{tabular}

characteristics of polypropylene microfibers utilized in this investigation were specified by the industrialist as shown in Table 2 .

\section{Mix design}

Geopolymer concrete mix proportion, which was considered in this work, was constantly mixed and, depending on Al-Shathr. et al [29], mixed with 0.0, 0.5, 1.0, and 1.5\% PPF as shown in Table 3, while Table 4 illustrates the description of each mix and the method of applied loading.

\section{Mixing, casting, and curing of samples}

The procedure which was designed for mixing GPC mixes was as follows: first, mix the dry component ( $\mathrm{MK}$, sand, and gravel) added progressively to the pan of mixer while the mixer was in rotary state for $2 \mathrm{~min}$ at low speed. Then, $65 \%$ of water and alkaline liquid with superplasticizer were added, whereas the mixer was at low speed, and then the PPF was added. Finally, the residual amount of water and alkaline liquid with superplasticizer was added, increasing the speed of the mixer for $2 \mathrm{~min}$.

Table 2 Properties of PPF

\begin{tabular}{ll}
\hline Chemical base & $\mathbf{1 0 0 \%}$ polypropylene \\
\hline Appearance/color & Transparent fibers \\
Density & $0.91 \mathrm{~g} / \mathrm{cm}^{3}$ \\
Dimensions & Diameter $32 \mu \mathrm{m}$ \\
& Length $12 \mathrm{~mm}$ \\
Product declaration & Class 1a: mono-filament (EN 14889-2) [28] \\
Melting point & $160{ }^{\circ} \mathrm{C}$ \\
Specific tensile strength & $\sim 30 \mathrm{cN} /$ tex \\
\hline
\end{tabular}


Table 3 Mix properties of geopolymer concrete

\begin{tabular}{llllll}
\hline $\begin{array}{l}\text { Metakaolin } \\
(\mathrm{MK})\left(\mathbf{k g} / \mathrm{m}^{3}\right)\end{array}$ & $\begin{array}{l}\text { Sand } \\
\left(\mathbf{k g} / \mathrm{m}^{3}\right)\end{array}$ & $\begin{array}{l}\text { Gravel } \\
\left(\mathbf{k g} / \mathrm{m}^{3}\right)\end{array}$ & $\begin{array}{l}\text { Alkaline solution } \\
\left(\mathbf{l i t} / \mathrm{m}^{3}\right)\end{array}$ & $\begin{array}{l}\text { Water } \\
\left(\mathrm{lit} / \mathrm{m}^{3}\right)\end{array}$ & $\begin{array}{l}\text { SP \% (from } \\
\text { metakaolin volume) }\end{array}$ \\
\hline 400 & 720 & 1100 & 180 & 40 & 3 \\
\hline
\end{tabular}

Vibrating table was used to consolidate the green concretes after being poured into the molds, and the molds were subjected to direct sunlight after demolding for 28 days as shown in Fig. 1.

\section{Results and discussions}

Slump test

The slump test was done according to ASTM C143-10a [30] on fresh mixes of geopolymer concrete immediately after mixing. The slump test results are illustrated in Fig. 2.

From Fig. 2, it can be concluded that the addition of PFF to GPC decreases the slump of concretes. The slump decreases from $3.5 \mathrm{~cm}$ of S1 to $2.8 \mathrm{~cm}$ for S5; this behavior of concretes was expected since the addition of fiber in general makes the concretes harsh and stiff which reduces its workability; these results conformed to the results of Ranjbar et al. [31].

\section{Compressive strength}

The compressive strength test was done according to BS EN 12390-3:2002 [32]. Three cubes with dimensions of $10 \times 10 \times 10 \mathrm{~cm}$ for each mixture were tested using a 2000 $\mathrm{kN}$ hydraulic compressor at the age of 28 days.

From Table 5, the compressive strength of GPCs in general enhanced with the addition of PPF increases with the increase of PPF to $0.5 \%$ and reached $34.7 \mathrm{MPa}$ compared to $31.2 \mathrm{MPa}$ for reference GPCs. But, after that, it starts reducing. These results conform to the results of Pham et al. [19].

\section{First crack load}

The central deflection was measured at the center of the panels $(40 \times 40 \times 5) \mathrm{cm}$, by using dial gage of $0.01 \mathrm{~mm}$ accuracy with $25 \mathrm{~mm}$ capacity as shown in Fig. 3 .

The first crack load means the load at which the first crack is created. The first crack load of all the GPC samples is illustrated in Table 6. For S2, the deflection is $8.235 \%$ lesser than S1 at the same first crack load. On the other hand, for S3, the deflection was less than S1 by $5.882 \%$ but with $25 \%$ increase in the first crack load, while for S5,

Table 4 Specimen nomenclature and description

\begin{tabular}{ll}
\hline Specimen ID & Description \\
\hline S1 & Reference GPC subjected to flexural strength \\
S2 & Reference GPC subjected to repeated loading \\
S3 & $0.5 \%$ PPFGPC subjected to flexural strength \\
S4 & $1.0 \%$ PPFGPC subjected to flexural strength \\
S5 & $1.5 \%$ PPFGPC subjected to flexural strength \\
S6 & $0.5 \%$ PPFGPC subjected to repeated loading \\
\hline
\end{tabular}




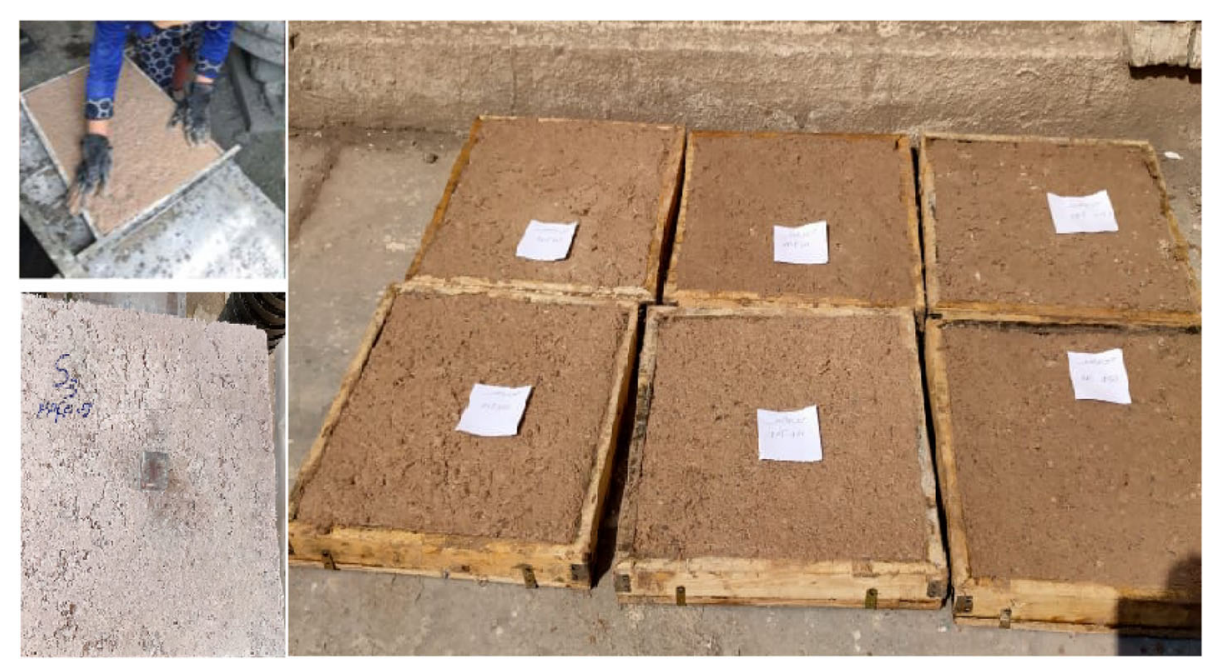

Fig. 1 Mixing, casting, and preparing to test of PPFGPCS

the first crack load increased by $50 \%$. It can be noticed that the fiber-reinforced geopolymer concretes have 50\% more load-bearing capacity than GPC samples at the first crack load; these results matched with the conclusions of Nath [33]. Pham et al. [19] tested the GPC reinforced with $0.5,1.0$, and 1.5\% volume fraction of PPF with SEM (Scanning Electron Microscopy) test; they concluded that the adhesion between PPF and base materials was excellent also; the paste around PPF was denser and improved compared to reference GPCs.

\section{Ultimate load}

The ultimate load is the maximum load-bearing capacity of the samples before failure. Table 6 shows the ultimate load of all panels. From Table 6, the deflection decreases from $11.5 \mathrm{~mm}$ for $\mathrm{S} 1$ to $8.0 \mathrm{~mm}$ in S5, while the volume of PPF increases (i.e., it decreases by $30.435 \%$ ), and the ultimate load was increased from $11 \mathrm{kN}$ in S1 to $16 \mathrm{kN}$ in S5 (the percentage increase was $45.45 \%$ ). This behavior may be attributed to the presence of PPF, as shown in Fig. 4.
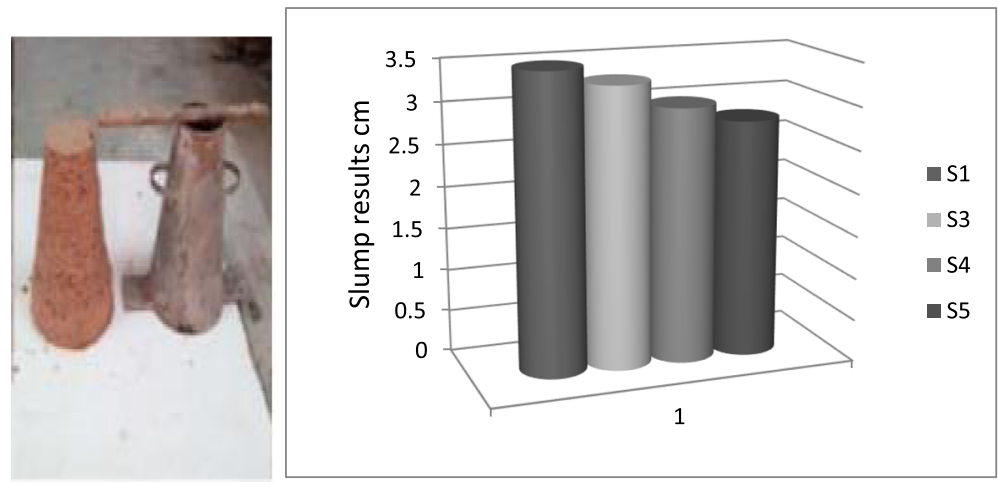

Fig. 2 Relationship between slump of GPCs and addition ratio of PPF 
Table 5 Compressive strength of GPC with and without PPF

\begin{tabular}{ll}
\hline \% of volume fraction of fiber & Compressive strength $\mathbf{M P a}$ \\
\hline 0.0 & 31.2 \\
0.5 & 34.7 \\
1.0 & 33.5 \\
1.5 & 32.3 \\
\hline
\end{tabular}

\section{Hysteresis behavior}

The deflection of the samples at each increment and decrement of the load was studied in the load control technique. $1.0 \mathrm{kN}$ load interval was used in the test to produce hysteresis loops of the samples. The hysteresis loop clearly defines the yield-deformation and maximum deformation of the specimen due to applied loading. The typical hysteresis loop behavior of normal GPC (S2) and GPCs with $0.5 \%$ of PPF (S6) at the 1st, 2nd, and 3rd loop are shown in Figs. 5, 6, 7, and 8.

From Figs. 5, 6, 7, and 8, it can be noticed that $\mathrm{S} 6$ have higher ultimate load (7 $\mathrm{kN}$ ) and less deflection (10.5 mm at failure (cycle 3)) compared to S2 which have 6 $\mathrm{kN}$ ultimate load and $12 \mathrm{~mm}$ deflection; also, the first cracking load was $4 \mathrm{kN}$ for both mixes at 1st cycle with 0.84 and $0.80 \mathrm{~mm}$ deflection at first crack load. From Figs. 2 and 3, the differences between deflection when increasing loading and decreasing it approximately equals along the cycle for S6 can be seen, while for S2, the differences are decreasing gradually. These behaviors may be attributed to existing PPF.

\section{Statistical test}

In this work with a view to detect the statistical value of the experimental work variables in a quantitative method, general linear model analysis of difference

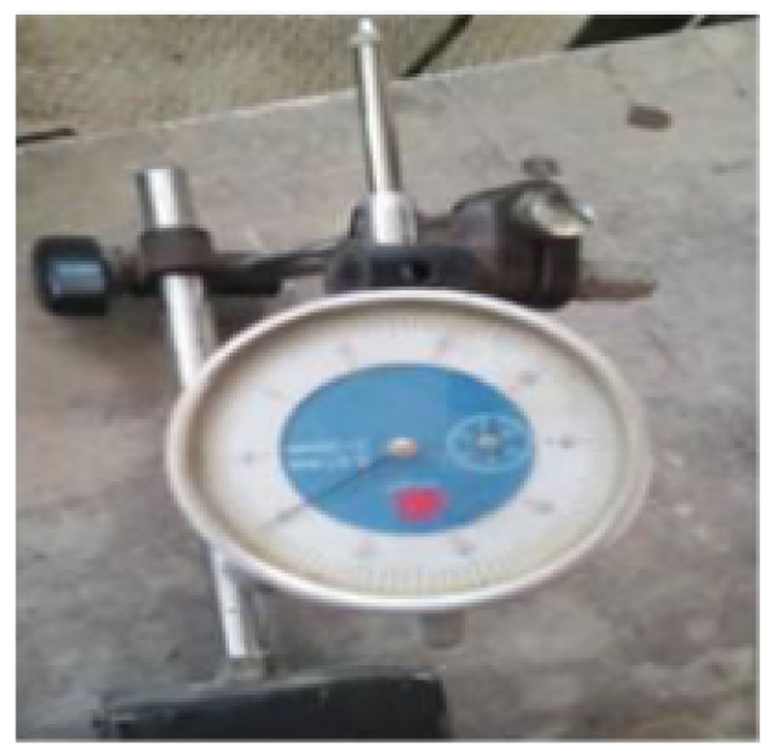

Fig. 3 Dial gage of $0.01 \mathrm{~mm}$ accuracy 
Table 6 Deflection at first crack load and ultimate load of samples

\begin{tabular}{lllll}
\hline $\begin{array}{l}\text { Sample } \\
\text { ID }\end{array}$ & $\begin{array}{l}\text { First crack load } \\
(\mathbf{k N})\end{array}$ & $\begin{array}{l}\text { Deflection at first crack load } \\
(\mathbf{m m})\end{array}$ & $\begin{array}{l}\text { Ultimate load } \\
(\mathbf{k N})\end{array}$ & $\begin{array}{l}\text { Deflection at ultimate } \\
\text { load }(\mathbf{m m})\end{array}$ \\
\hline S1 & 4 & 0.85 & 11 & 11.5 \\
S3 & 4 & 0.78 & 12 & 10.0 \\
S4 & 5 & 0.8 & 15 & 9.15 \\
S5 & 6 & 1.28 & 16 & 8.0 \\
\hline
\end{tabular}

GLM-ANOVA was used 0.05 as a level of significance. GLM-ANOVA is a program assistance in decreasing the error differences and indicates the dominance of a control factor and is considered a significant statistical analysis and diagnostic tool. In the analysis, the measured deflection for PPFGPCs were appointed as the dependent variables while the volume fraction of PPF, first crack load, and ultimate load was chosen as the independent factors. GLM-ANOVA was used, and their percent contributions and the effective test parameters on the deflection results are shown in Table 7. The independent variable is accepted as a significant factor on the test results when the $P$ value is less than 0.05 . The degree of effectiveness of the independent factors on the measured property which is known as the percent contribution was also determined. When the effectiveness of that parameter on the

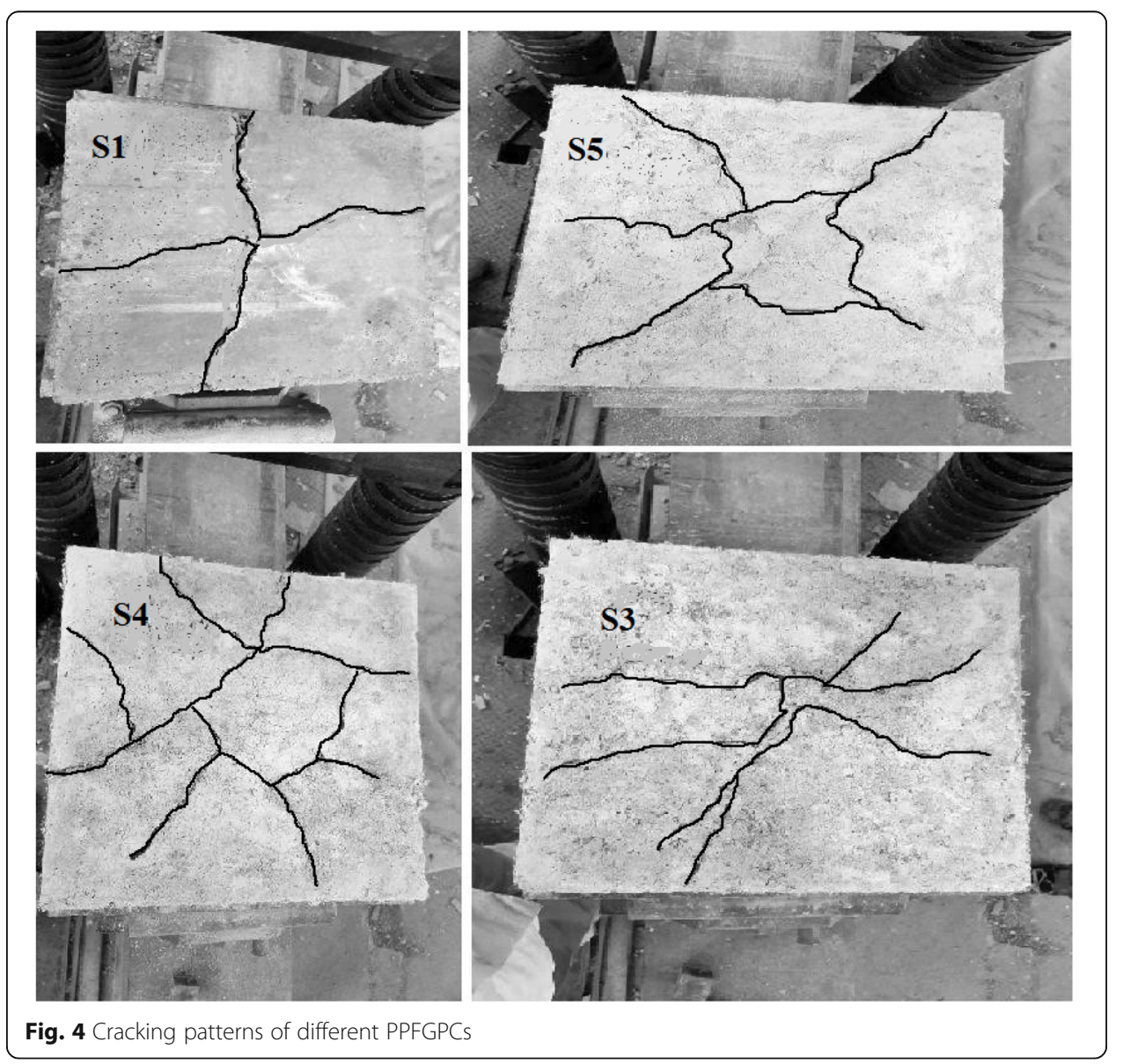




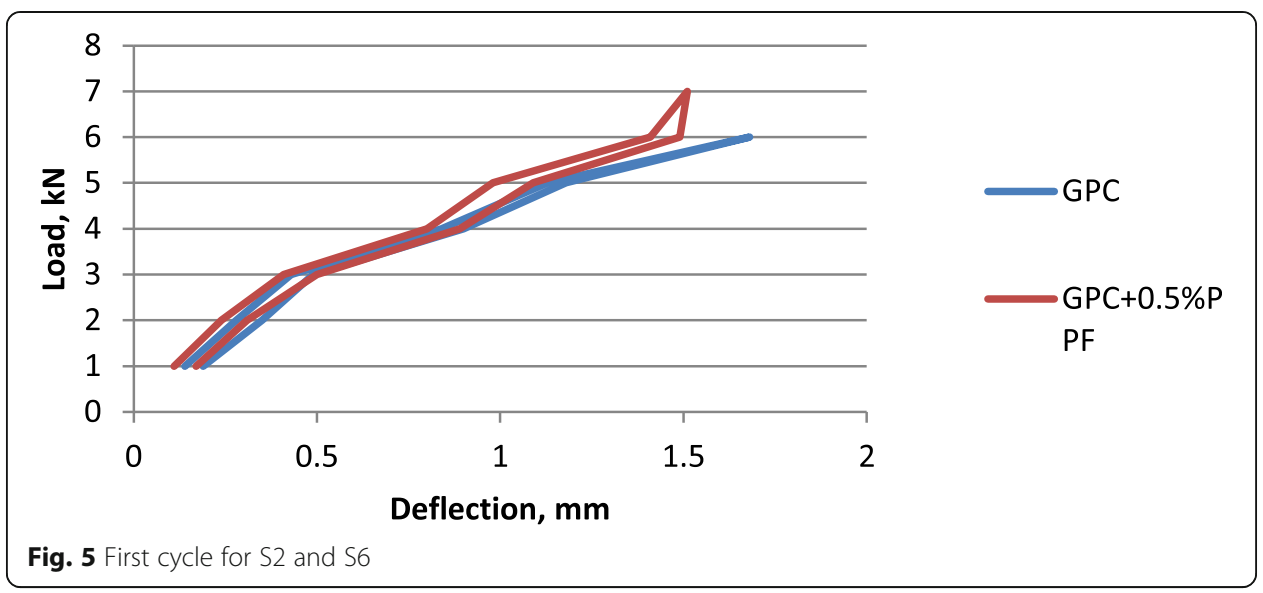

measured property is higher, that leads to increase the percent contribution. Likewise, if the input of the factor to that certain reaction is less, that means the percent contribution is low. The statistical evaluation of the test results indicated that all independent variables had a remarkable effect on the deflection of the mixtures when $P$ values of the independent variables were considered.

\section{Conclusions}

This study tested the deflection of metakaolin-based geopolymer reinforced by polypropylene fibers (PPF) under static and repeated flexural loading, in addition to slump test for fresh concretes and statistical test for the results. The following conclusions were noticed according to our experiments:

1- As the amount of fibers increases, the workability of the PPFGPCs decreases significantly due to the shear resistance to flow.

2- The compressive strength of GPC increases with $0.5 \%$ addition of PPF, but, after that, it started to reduce.

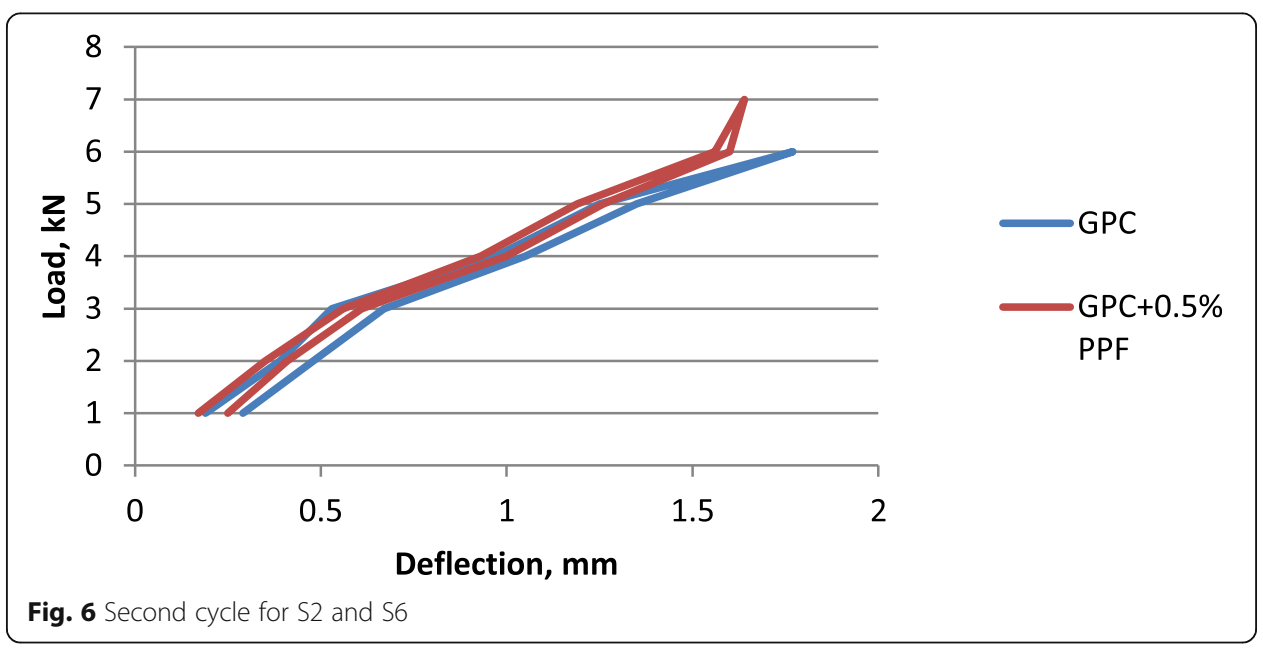




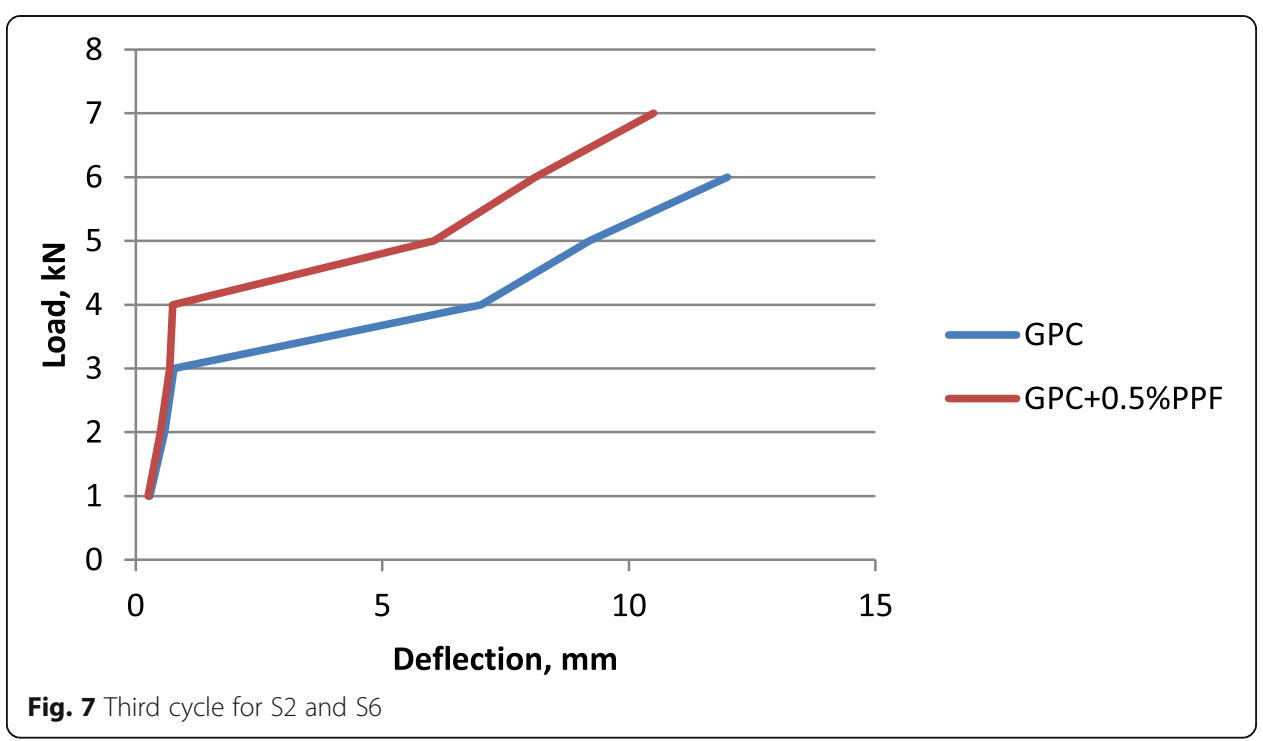

3- As the fiber percentage increases in the GPCs, the flexural strength increases compared to GPC without fiber; also, the load of the first crack increases as the amount of fiber increases.

4- The deflection of PPFGPCs decreases as the fiber content increases at the same load; this relation is applied for static and repeated flexural loading; this behavior leads to the enhanced energy absorption (flexural toughness) of the material.

5- The effect of PPF volume, first crack load, and ultimate load was statistically tested, and it was seen that all independent parameters, PPF volume, first crack load, and ultimate load, had a significant effect on the deflection of the PPFGPCs regarding to $P$ values. However, the most effective independent parameter was the PPF volume according to percent contribution values.

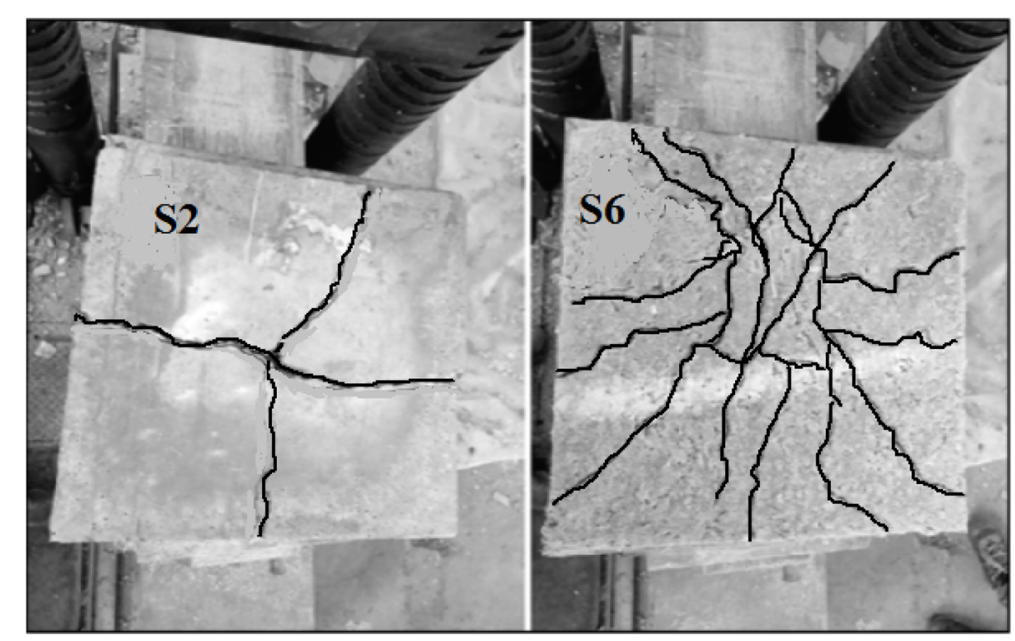

Fig. 8 Cracking patterns for S2 and S6 after 3 cycles of loading and unloading 
Table 7 Statistical evaluation of deflection of PPFGPCs

\begin{tabular}{|c|c|c|c|c|c|c|c|}
\hline $\begin{array}{l}\text { Dependent } \\
\text { variable }\end{array}$ & $\begin{array}{l}\text { Independent } \\
\text { variable }\end{array}$ & $\begin{array}{l}\text { Sequential sum } \\
\text { of squares }\end{array}$ & $\begin{array}{l}\text { Computed } \\
\text { F }\end{array}$ & $\begin{array}{l}\text { R } \\
\text { squares } \\
\%\end{array}$ & $\begin{array}{l}P \\
\text { value }\end{array}$ & Significance & $\begin{array}{l}\text { Contribution } \\
\%\end{array}$ \\
\hline \multirow[t]{5}{*}{ Deflection } & PPF volume & 0.002773 & 113.7 & 90.8 & 0.01 & Yes & 45.6 \\
\hline & $\begin{array}{l}\text { First crack } \\
\text { load }\end{array}$ & 0.001917 & 26.7 & & 0.03 & Yes & 28.0 \\
\hline & Ultimate load & 0.001117 & 15.3 & & 0.02 & Yes & 19.9 \\
\hline & Error & 0.000586 & - & & & & 6.5 \\
\hline & Total & 0.006392 & - & & & & - \\
\hline
\end{tabular}

\section{Abbreviations}

PPF: Polypropylene microfibers; GPC: Geopolymer concrete; PPFGPC: Polypropylene fiber-reinforced geopolymer concrete; FA: Fly ash; MK: Metakaolin; SP: Superplasticizer; ASTM: American Society for Testing and Materials

\section{Acknowledgements}

The authors would like to thank Al-Mustansiriyah University (www.uomustansiriyah.edu.iq) Baghdad-Iraq for its support in the present work.

\section{Authors' contributions}

The team cast the samples and examined them. AM analyzed the results, and OM wrote the manuscript. All researchers read the manuscript and approved it.

\section{Funding}

This study had no funding from any resource.

\section{Availability of data and materials}

All data and materials will be available upon request.

\section{Declaration}

\section{Competing interests}

There is no conflict of interest between the authors.

Received: 29 April 2021 Accepted: 2 August 2021

Published online: 14 October 2021

\section{References}

1. Ambily PS (2014) Development of ultra-high- performance geopolymer concrete. Mag Concr Res 66(2):82-89. https:// doi.org/10.1680/macr.13.00057

2. Ibrahim AK, AL-Kerttani O, Abbas SR (2020) Properties of geopolymer mortar subjected to high temperature. Key Eng Mater 858:193-198. https://doi.org/10.4028/www.scientific.net/KEM.858.193

3. Kim D, Lai HT, Yen TF (2006) Geopolymer formation and its unique properties. Environ Geol 51(1):103-111. https://doi. org/10.1007/s00254-006-0308-z

4. Davidovits J, Comrie DC, Paterson JH, Ritcey DJ (1990) Geopolymeric concretes for environmental protection. Concr Int 12:30-40

5. Davidovits J (2005) Geopolymer chemistry and sustainable development, the poly (sialate) terminology: a very useful and simple model for the promotion and understanding of green-chemistry. Geopolymer Proc:9-15

6. Ren W, Xu J, Liu J, Su H (2015) Dynamic mechanical properties of geopolymer concrete after water immersion. Ceram Int 41(9):11852-11860. https://doi.org/10.1016/j.ceramint.2015.05.154

7. Davidovits J (1999) Chemistry of geopolymeric systems. In: Terminology, Geopolymer '99 Int. Conf. Technol, Compiegne, pp 9-40

8. Palomo A, Grutzeck MW, Blanco MT (1999) Alkali-activated fly ashes: a cement for the future. Cem Concr Res 29(8): 1323-1329. https://doi.org/10.1016/50008-8846(98)00243-9

9. Barbosa VF, MacKenzie KJ, Thaumaturgo C (2000) Synthesis and characterisation of materials based on inorganic polymers of alumina and silica: sodium polysialate polymers. Int J Inorg Mater 2(4):309-317. https://doi.org/10.1016/S14 66-6049(00)00041-6

10. Xu H, Van Deventer JSJ (2000) The geopolymerisation of alumino-silicate minerals. Int J Miner Process 59(3):247-266. https://doi.org/10.1016/S0301-7516(99)00074-5

11. Rickard WDA, Vickers L, Van Riessen A (2013) Performance of fibre reinforced, low density metakaolin geopolymers under simulated fire conditions. Appl Clay Sci 73:71-77 [CrossRef]

12. Korniejenko K, Lin W-T, Šimonová H (2020) Mechanical properties of short polymer fiber-reinforced geopolymer composites. J Compos Sci 4(3):128. https://doi.org/10.3390/jcs4030128

13. Ranjbar N, Mehrali M, Alengaram UJ, Jumaat MZ (2015) Graphene nanoplatelet-fly ash based geopolymer composites. Cem Concr Res 76(0):222-231. https://doi.org/10.1016/j.cemconres.2015.06.003 
14. Mackenzie K, Welter M (2014) Geopolymer (aluminosilicate) composites: synthesis, properties and applications. Adv Ceramic Matrix Composites 545-568.

15. Puertas F, Amat T, Fernandez-Jimenez A, Vazquez T (2003) Mechanical and durable behaviour of alkaline cement mortars reinforced with polypropylene fibres. Cem Concr Res 33:2031-2036 [CrossRef]

16. Zhang ZH, Yao X, Zhu HJ, Hua SD, Chen Y (2009) Preparation and mechanical properties of polypropylene fiber reinforced calcined kaolin-fly ash based geopolymer. J Cent South Univ Technol 16(1):49-52. https://doi.org/10.1007/s11 771-009-0008-4

17. Zhu J, Zheng WZ, Qin CZ, Xu ZZ, Wu YQ (2018) Effect of different fibers on mechanical properties and ductility of alkaliactivated slag cementitious material. IOP Conf Ser Mater Sci Eng 292:012060 [CrossRef]

18. Wang Y, Zheng T, Zheng X, Liu Y, Darkwa J, Zhou G (2020) Thermo-mechanical and moisture absorption properties of fly ash-based lightweight geopolymer concrete reinforced by polypropylene fibers. Construct Build Mater 251:118960 [CrossRef]

19. Pham KVA, Nguyen TK, Le TA, Han SW, Lee G, Lee K (2019) Assessment of performance of fiber reinforced geopolymer composites by experiment and simulation analysis. Appl Sci 9:3424 [CrossRef]

20. Behforouz B, Balkanlou VS, Naseri F, Kasehchi E, Mohseni E, Ozbakkaloglu T (2020) Investigation of eco-friendly fiberreinforced geopolymer composites incorporating recycled coarse aggregates. Int J EnvironSci Technol 17:3251-3260 [CrossRef]

21. Yuan Y, Zhao R, Li R, Wang Y, Cheng Z, Li F, Ma ZJ (2020) Frost resistance of fiber-reinforced blended slag and Class F fly ash-based geopolymer concrete under the coupling effect of freeze-thaw cycling and axial compressive loading. Construct Build Mater 250:118831 [CrossRef]

22. Su Z, Guo L, Zhang Z, Duan P (2019) Influence of different fibers on properties of thermal insulation composites based on geopolymer blended with glazed hollow bead. Construct Build Mater 203:525-540 [CrossRef]

23. Utami FAR, Triwiyono A, Agustini NKA, Perdana I (2020) Thermal conductivity of geopolymer with polypropylene fiber. IOP Conf Ser Mater Sci Eng 742:012031 [CrossRef]

24. Mohseni E, Kazemi MJ, Koushkbaghi M, Zehtab B, Behforouz B (2019) Evaluation of mechanical and durability properties of fiber-reinforced lightweight geopolymer composites based on rice husk ash and nanoalumina. Construct Build Mater 209:532-540 [CrossRef]

25. Aygörmez Y, Canpolat O, Al-Mashhadani MM, Uysal M (2020) Elevated temperature, freezing-thawing and wettingdrying effects on polypropylene fiber reinforced metakaolin based geopolymer composites. Construct Build Mater 235 117502 [CrossRef]

26. ASTM (2010) C618, Standard specification for coal fly ash and raw or calcined natural pozzolan for use in concrete. Annu B ASTM Stand 3-6. https://doi.org/10.1520/C0618

27. ASTM C494M-19 (2013) Standard specification for chemical admixtures for concrete. ASTM Int:1-15

28. EN 14889-2, BS EN 14889-2 (2018) Fibres for concrete. Part 2. Polymer fibres. Definition, pecifications and conformity. 18/ 30377670 DC

29. Al-Shathr BS, Al-Attar TS, Zaid AH (2015) Optimization of geopolymer concrete based on local Iraqi metakaolin. In: The 2nd International Conference of Buildings, Construction and Environmental Engineering, pp 97-100

30. ASTM C143 / C143M - 10a (2010) Standard test method for slump of hydraulic-cement concrete. American National Standard

31. Ranjbar N, Mehrali M, Behnia A, Pordsari AJ, Mehrali M, Alengaram UJ, Jumaat MZ (2016) A comprehensive study of the polypropylene fiber reinforced fly ash based geopolymer. PLoS One 1-20. https://doi.org/10.1371/journal.pone.0147546

32. BS EN 12390-3 (2002) Testing concrete. Method for determination of compressive strength of concrete cubes, pp 1-10

33. Nath S (2018) Behavior of fiber reinforced geopolymer concrete beam column joint under cyclic loading. Int I Civil Eng Technol 9(4):355-364

\section{Publisher's Note}

Springer Nature remains neutral with regard to jurisdictional claims in published maps and institutional affiliations.

\section{Submit your manuscript to a SpringerOpen ${ }^{\circ}$ journal and benefit from:}

- Convenient online submission

- Rigorous peer review

- Open access: articles freely available online

- High visibility within the field

- Retaining the copyright to your article

Submit your next manuscript at $\mathbf{s p r i n g e r o p e n . c o m ~}$ 